\title{
Effect of Light and pH on the Growth of Sclerotium rolfsii in vitro on Collar Rot of Indian Bean
}

\author{
Tushar V. Ghevariya* and P. R. Patel \\ Department of Plant Pathology, NM College of Agriculture, Navsari Agricultural University, \\ Navsari - 396 450, Gujarat, India \\ *Corresponding author
}

\section{A B S T R A C T}

\begin{tabular}{|l|}
\hline Key w or d s \\
$\begin{array}{l}\text { Sclerotium rolfsii, } \\
\text { pH, Light }\end{array}$ \\
\hline Article Info \\
\hline $\begin{array}{l}\text { Accepted: } \\
\text { 10 September } 2019 \\
\text { Available Online: } \\
10 \text { October } 2019\end{array}$ \\
\hline
\end{tabular}

Sclerotium rolfsii is one of the most important soil-borne plant pathogen which cause severe loss at the time of seedling development. It also causes collar rot in several crops and wild plants. In this experiment, exposure of pathogen to different light period and $\mathrm{pH}$ in order to assess the mycelial growth and number of sclerotia of $S$. rolfsii was done. For the light experiment three plate continues dark, light and 12 hour interval. All the plates were incubated at $28 \pm 1^{\circ} \mathrm{C}$. The results reveal that there was no significant difference in mycelial growth and number of sclerotia among them but significant difference was observed when compared with the 12 hour interval. The light condition induces the production of more number of sclerotia than dark condition. In alternative cycles of 12 hour light and 12 hour darkness for ten days resulted in the maximum mycelium growth, more number of sclerotia was also seen when compared with continued light and dark condition. Effect of eight $\mathrm{pH}$ levels viz., 5.0, 5.5, 6, 6.5, 7, 7.5, 8 and 8.5 on radial growth and sclerotia formation of $S$. rolfsii was studied and observations. Mycelium growth was observed at all the $\mathrm{pH}$ levels tested but it was maximum at $\mathrm{pH} 6.5(87.00 \mathrm{~mm})$ after $72 \mathrm{hrs}$ of inoculation. $\mathrm{pH} 6.0(85.25 \mathrm{~mm})$ and $\mathrm{pH} 5.5(83.75 \mathrm{~mm})$ were also found favorable. Excellent sclerotia formation was observed at $\mathrm{pH} 5.5,6.0$ and 6.5 while fair sclerotia production was recorded at $\mathrm{pH} 5.0,7.0$ and 7.5 and $\mathrm{pH} 8.0$ and 8.5 supported poor sclerotia formation. Highly acidic and alkaline $\mathrm{pH}$ is not suitable for the growth of pathogen.

\section{Introduction}

Indian bean (Lablab purpureus L.) belonging to family Fabaceae, is one of the most ancient among the cultivated crops and is presently grown throughout the tropical regions in Asia, Africa and America. Variety typicus is a garden type and cultivated for its soft and edible pods. Variety lignosus is known as field bean and mainly cultivated for dry seed as pulse. It is commonly known as Hyacinth bean, Dolichos bean, Avare (Kannada), Anumulu (Telugu), Avaria (Tamil), Indian bean, lablab bean, sembean, lubia bean (Sudan), wal-papdi (Gujarat) and Egyptian Kidney bean. Sclerotium rolfsii Sacc. is an important soil borne pathogen with more than 500 plant species including vegetable, 
ornamental, pulse, oilseed and medicinal crops are attacked by this pathogen (Farr et al., 1989). In 1892 Peter Henery Rolfs published a description of new disease on tomato. Some fields in Florida showed > $70 \%$ loss. Saccardo later named the fungus as $S$. rolfsii in 1911. Several fungi which previously belonged to form genus Sclerotium have since been placed in more appropriate genera with the discovery of associated telemorphs Sclerotium rolfsii Sacc., first reported by Rolfs in Florida (1892) is a serious fungal pathogen. $S$. rolfsii is an important soil borne pathogen, which cause severe damage to many economically important crops and plant. Severe damage is caused to Soybean, Linseed, Groundnut, Chickpea, Sunflower, Safflower, Beans, Cloves, Peas, Niger and Lentil. It has a wide host range as it affects plants belonging to nearly 100 families. Diseases caused by $S$. rolfsii are initiated either directly from soilborne sclerotia which germinate to form fine cottony hyphae infecting the collar region of host plants or sclerotia sticking on the lower/upper surfaces of the leaves by rain splashes where they germinate and cause leaf spots (Singh and Pavgi,1965). Various biotic and abiotic factors which directly or indirectly influence the development of sclerotia were discussed in literature (Sarma, 2002).

\section{Materials and Methods}

\section{Isolation, identification and maintenance of pathogen}

The collar rot symptoms were collected from the field of Pulse Research Station, Navasari Agriculture University, Navasari, Gujarat, India. The infected plant materials brought back from the field were washed, cut into $5 \mathrm{~mm}$ segments including the advancing margins of infection. The segments were surface sterilized in $0.5 \%$ sodium hypochlorite solution for $5 \mathrm{~min}$. and rinsed in three changes of sterile distilled water. The segments were separately dried in between sheets of sterile filter paper and placed ( 3 pieces per plate) on fresh potato dextrose agar (PDA) medium (Ainsworth, 1961) impregnated with streptomycin and incubated for seven days at $28 \pm 1^{\circ} \mathrm{C}$. The fungal growth on 5th day, which arose through the sclerotial bodies was cut by inoculation loop and transferred aseptically to the PDA slants and allowed to grow at room $\left(28 \pm 1^{\circ} \mathrm{C}\right)$ temperature to obtain the pure culture of the fungus. The culture thus obtained was stored in refrigerator at $5^{\circ} \mathrm{C}$ for further studies and was sub cultured periodically. The purified isolate was identified as $S$. rolfsii based on morphological and colony characteristics (Punja and Damini, 1996; Sarma et al., 2002; Watanabe, 2002).

\section{Effect of light on the growth of $S$. rolfsii.}

The pathogen were grown study on PDA media, $20 \mathrm{ml}$ of potato dextrose agar was poured in $90 \mathrm{~mm}$ sterile Petri plate. Such plates were inoculated with five $\mathrm{mm}$ mycelial disc obtained from the periphery of Ten days old culture of $S$. rolfsii and incubated at different light hours viz., alternate cycles of twelve hours light and twelve hours darkness in an environmental conditions, continuous light in constant environment room Beneath a bank of Philips 'Warm White' fluorescent tubes at $25^{\circ} \mathrm{C}$ with a radiant flux at bench level of $38.0 \mathrm{Wm}^{-2}$ and continuous darkness for three dishes were incubated in the same chamber but were first sealed in cardboard boxes which were then wrapped in two layers of aluminium foil. At 12 hour intervals, all dishes were examined for signs of sclerotium formation.

During examination, dark-grown colonies were exposed to diffuse daylight for a few minutes but preliminary experiments had shown that this treatment had in detectable effect on sclerotium production. After 21 days, the number of sclerotia on each colony was counted. 
Effect of various $\mathrm{pH}$ on growth and sclerotia formation of Sclerotium rolfsii

The set of different $\mathrm{pH}$ viz., 5.0, 5.5, 6, 6.5, 7, $7.5,8$ and 8.5 were prepared and $\mathrm{pH}$ was adjusted by adding appropriate amount of $\mathrm{HCl}$ and $\mathrm{NaOH}$ in the PDA medium. For each $\mathrm{pH}$ value, there were four replications. PDA was taken as basal medium. The medium as pipetted in 100ml Erlenmeyer flask and the $\mathrm{pH}$ of medium was adjusted to desired level by using $\mathrm{N} / 10 \mathrm{HCl}$ or $\mathrm{N} / 10 \mathrm{NaOH}$. The pathogen were grown study on PDA media, $20 \mathrm{ml}$ of potato dextrose agar was poured in $90 \mathrm{~mm}$ sterile Petri plate. Such plates were inoculated with five $\mathrm{mm}$ mycelial disc and incubated at $28 \pm 1{ }^{\circ} \mathrm{C}$. At the interval of 24 hour, the linear growth was measured till 3 days. The number of sclerotia formation per plate was recorded after 15 days.

\section{Results and Discussion}

The results of the present study reveal that the number of sclerotia in light and darkness affected the mycelium growth and number of sclerotia significantly as compared to the control. In the control plates, sclerotia initials were observed after seven days of inoculation as whitish, tiny, pinhead-like structures and after 6-8 days exudation commenced. Sclerotia are the asexual structures formed due to the aggregation of fungal mycelium. Several biotic and abiotic factors influence the aggregation of fungal hyphae in the culture medium. Punja and Damini (1996) and Singh et al., (2002) reported that sclerotial exudates directly influenced the development and maturation of sclerotia.

The exposure of the pathogen to alternative cycles of $12 \mathrm{~h}$ light and $12 \mathrm{~h}$ darkness for ten days resulted in the maximum mycelial growth $(88.66 \mathrm{~mm})$ with more number of sclerotia/ plate of $S$. rolfsii which was significantly superior over other treatments tested (Table 1). The mycelial growth of pathogen exposed to continuous light resulted in moderate growth $(70.75 \mathrm{~mm})$ and continuous darkness resulted in minimum mycelial growth of $S$. rolfsii $(49.00 \mathrm{~mm})$. Similarly, Basamma (2008) reported that, $S$. rolfsii was exposed to alternate cycles of $12 \mathrm{~h}$ light and $12 \mathrm{~h}$ darkness recorded more number of sclerotia of $S$. rolfsii. This is in agreement with the findings of Chung and Kim (1977).

$\mathrm{pH}$ of the media is one of the important factors which influence the growth of the fungus. In general fungal pathogen prefer acidic to neutral $\mathrm{pH}$ for development and growth (Plate 1 and 2).

Data presented in (Table 2 and Plate 3) revealed that $S$. rolfsii was able to mycelium grow and produce sclerotia with wide range (Plate 4) of $\mathrm{pH}$ level that is, $\mathrm{pH} 5.0$ to 8.5. The maximum radial growth of the fungus was observed at $\mathrm{pH} 6.5(87.00 \mathrm{~mm})$ followed by $\mathrm{pH} 6.0(85.25 \mathrm{~mm})$ and $5.5(83.75 \mathrm{~mm})$. The optimum $\mathrm{pH}$ level for the growth and sclerotia formation by the fungus ranged from $\mathrm{pH} 6.0$ to 6.5. Maximum numbers of sclerotia were found from $\mathrm{pH} 5.5$ to 6.5 Intensity of sclerotia was slowly affected by increase or decrease of $\mathrm{pH}$ level. These results were in confirmation with Zape et al., (2013) who reported that the maximum radial growth of $S$. rolfsii was observed at $\mathrm{pH} 6.5$ followed by $\mathrm{pH} 6.0$ and 5.5 whereas, for formation of sclerotia, it was at $\mathrm{pH}$ 7.0.

Optimum $\mathrm{pH}$ for the mycelia growth and formation of sclerotia by $S$. rolfsii was $\mathrm{pH} 5.0$ to 7.5 Different workers have reproted different optima for sclerotia formation by their isolate of Sclerotium rolfsii. Sharma and Kaushal (1979) have observed maximum sclerotial development between $\mathrm{pH} 5.2$ to 5.8 in $S$. rolfsii isolated from sunflower. In the present study $\mathrm{pH} 5.5$ to 6.5 were found to be most favorable for the radial growth and production of sclerotia. 
Table.1 Effect of light on the growth of S. rolfsii in PDA

\begin{tabular}{|c|c|c|}
\hline Treatments & Mycelia growth $(\mathbf{m m})$ & Sclerotium no. per plate \\
\hline Continuous light & $\mathbf{7 0 . 7 5}^{\mathbf{b} *}$ & $\mathbf{1 4 5}^{\text {b* }}$ \\
\hline Continuous dark & $\mathbf{4 9 . 0 0}^{\mathbf{c}}$ & $\mathbf{7 0}^{\mathrm{c}}$ \\
\hline $\begin{array}{c}\text { Alternate cycle of } 12 \text { h light } \\
\text { and } 12 \text { h darkness }\end{array}$ & $\mathbf{8 8 . 6 6}^{\mathbf{a}}$ & $\mathbf{1 9 5}^{\mathbf{a}}$ \\
\hline
\end{tabular}

*Values in each column followed by the same letter are not significantly different according to the DMRT method $(\mathrm{P}=0.05)$.

Table.2 Effect of various $\mathrm{pH}$ on radial growth and sclerotia formation of $S$. rolfsii

\begin{tabular}{|c|c|c|c|c|}
\hline S. No. & pH & Radial growth $(\mathbf{m m})$ & Type of colony & $\begin{array}{c}\text { Sclerotia formed after 21 } \\
\text { day }\end{array}$ \\
\hline $\mathbf{1}$ & 5.0 & 76.75 & Fluffy & Fair \\
\hline $\mathbf{2}$ & 5.5 & 83.75 & Fluffy & Excellent \\
\hline $\mathbf{3}$ & 6.0 & 85.25 & Fluffy & Excellent \\
\hline $\mathbf{4}$ & 6.5 & 87.00 & Fluffy & Excellent \\
\hline $\mathbf{5}$ & 7.0 & 55.25 & Appressed & Fair \\
\hline $\mathbf{6}$ & 7.5 & 49.00 & Appressed & Fair \\
\hline $\mathbf{7}$ & 8.0 & 42.75 & Dense compact & Poor \\
\hline $\mathbf{8}$ & 8.5 & 36.75 & Dense compact & Poor \\
\hline \multicolumn{2}{|c|}{ SEm $\mathbf{C D}$} & 0.73 & & \\
\hline CD at 5\% & 2.12 & & \\
\hline \multicolumn{2}{|c|}{ CV \% } & 2.25 & & \\
\hline
\end{tabular}

*Average of 4 replications

Plate.1 In vitro condition mycelium growth of $S$. rolfii on PDA

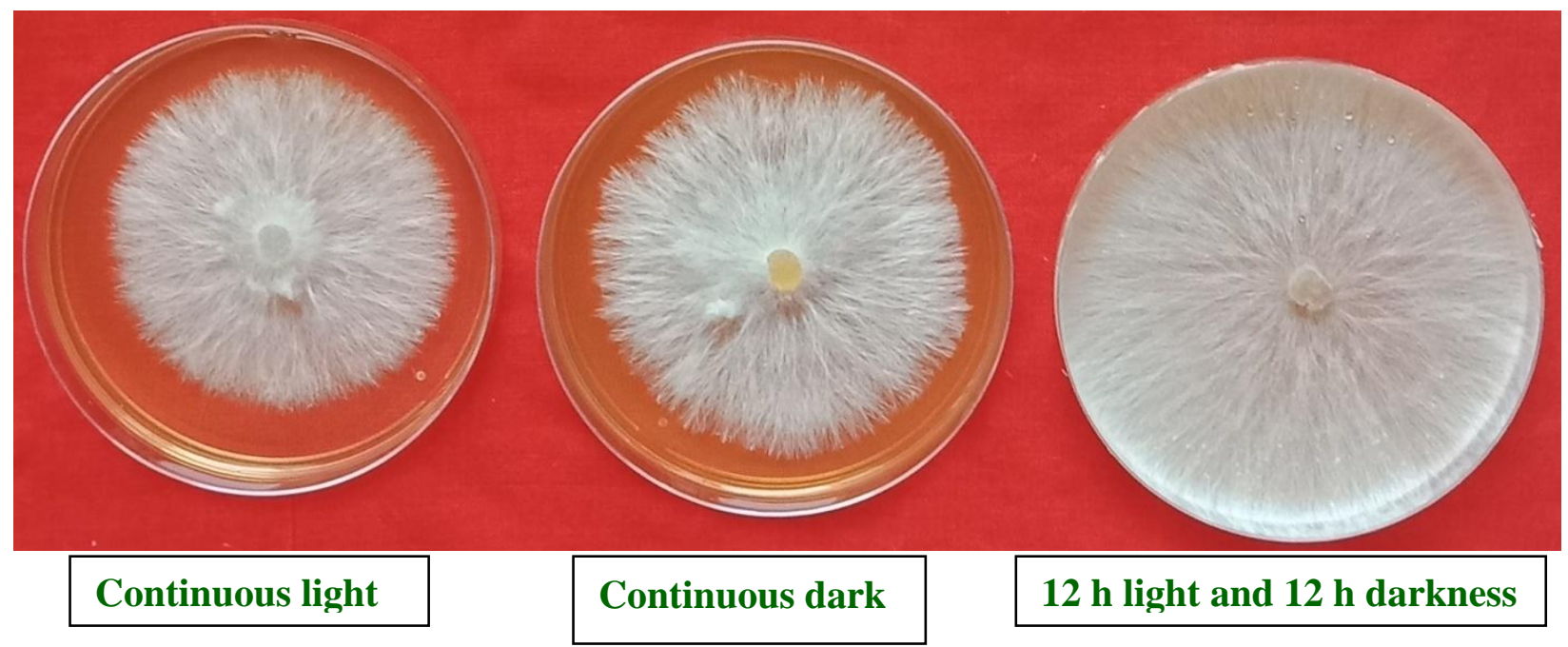


Plate.2 Sclerotia formed after 21 day

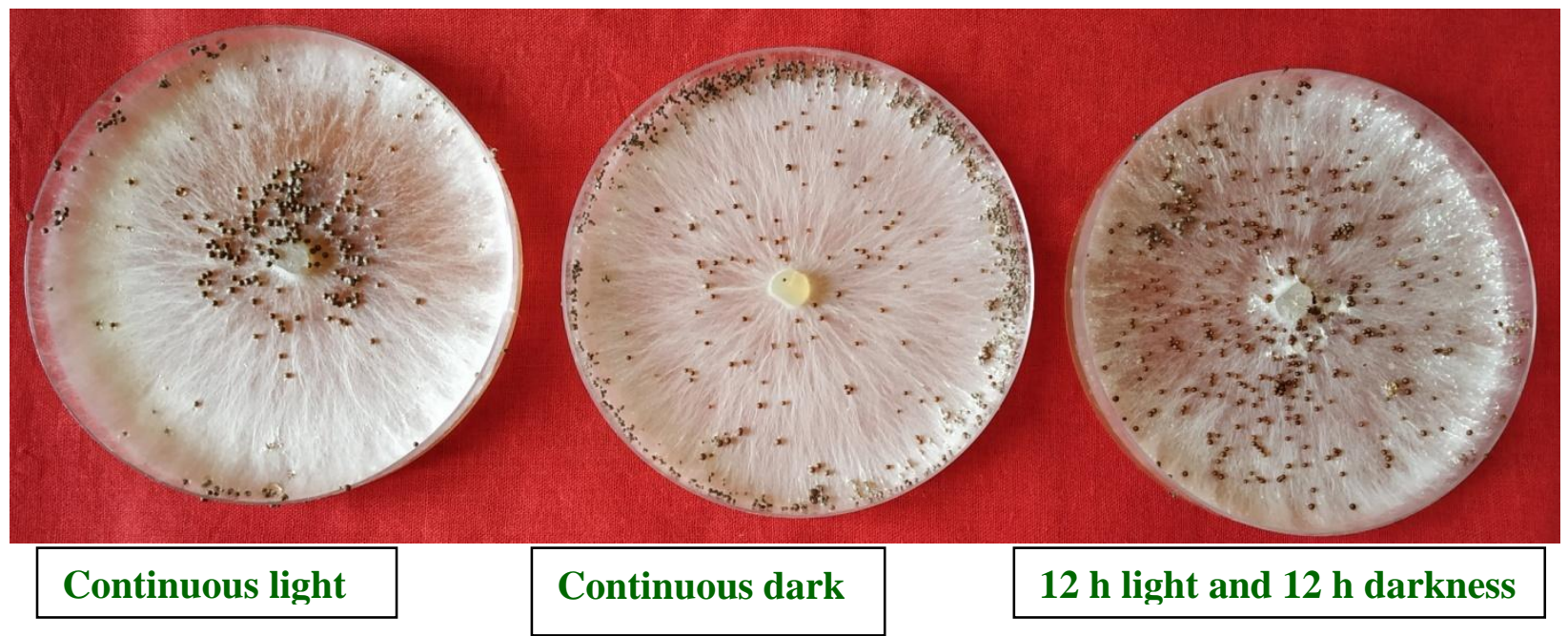

Plate.3 In vitro condition mycelium growth of $S$. rolfii on PDA

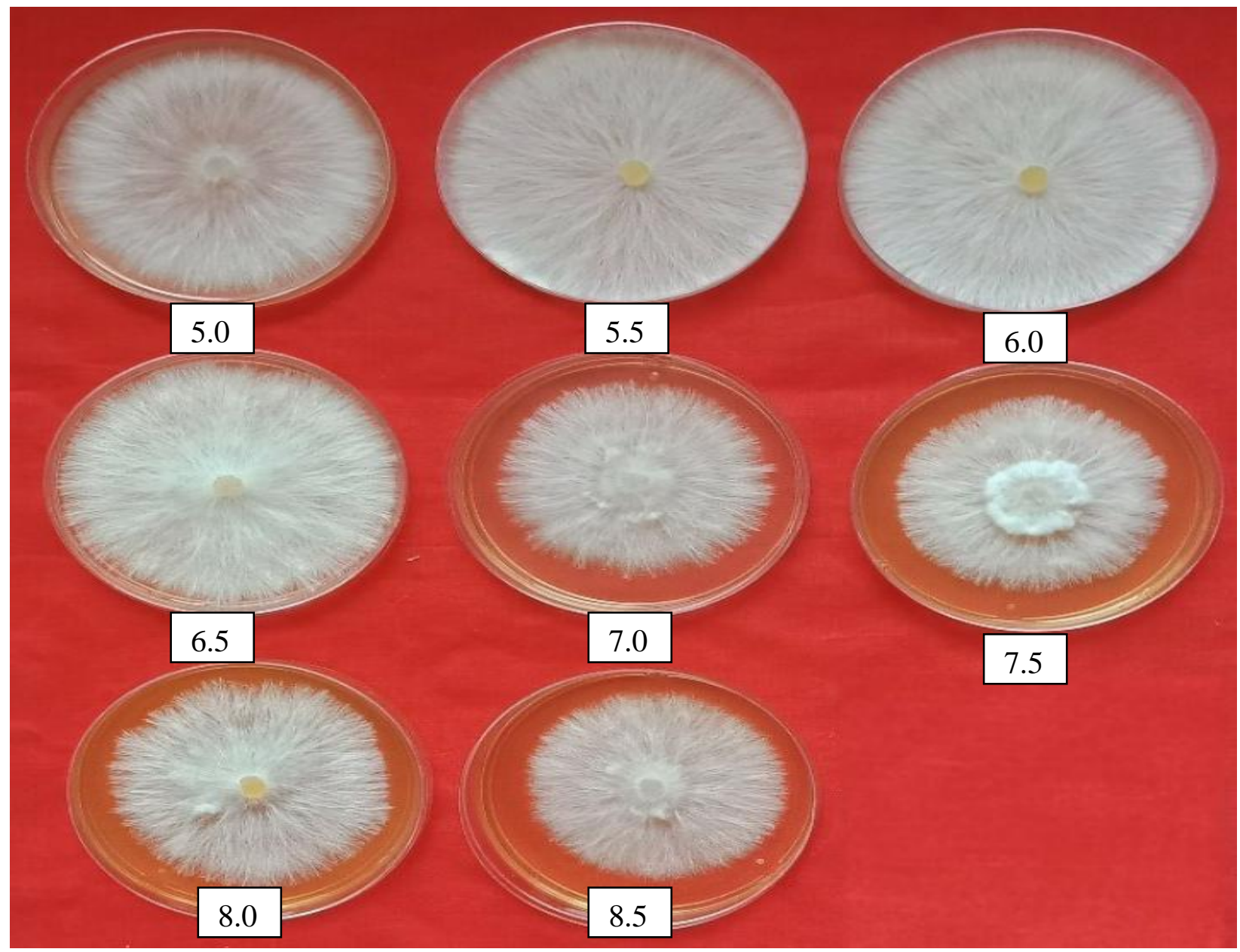


Plate.4 Sclerotia formed after 21 day

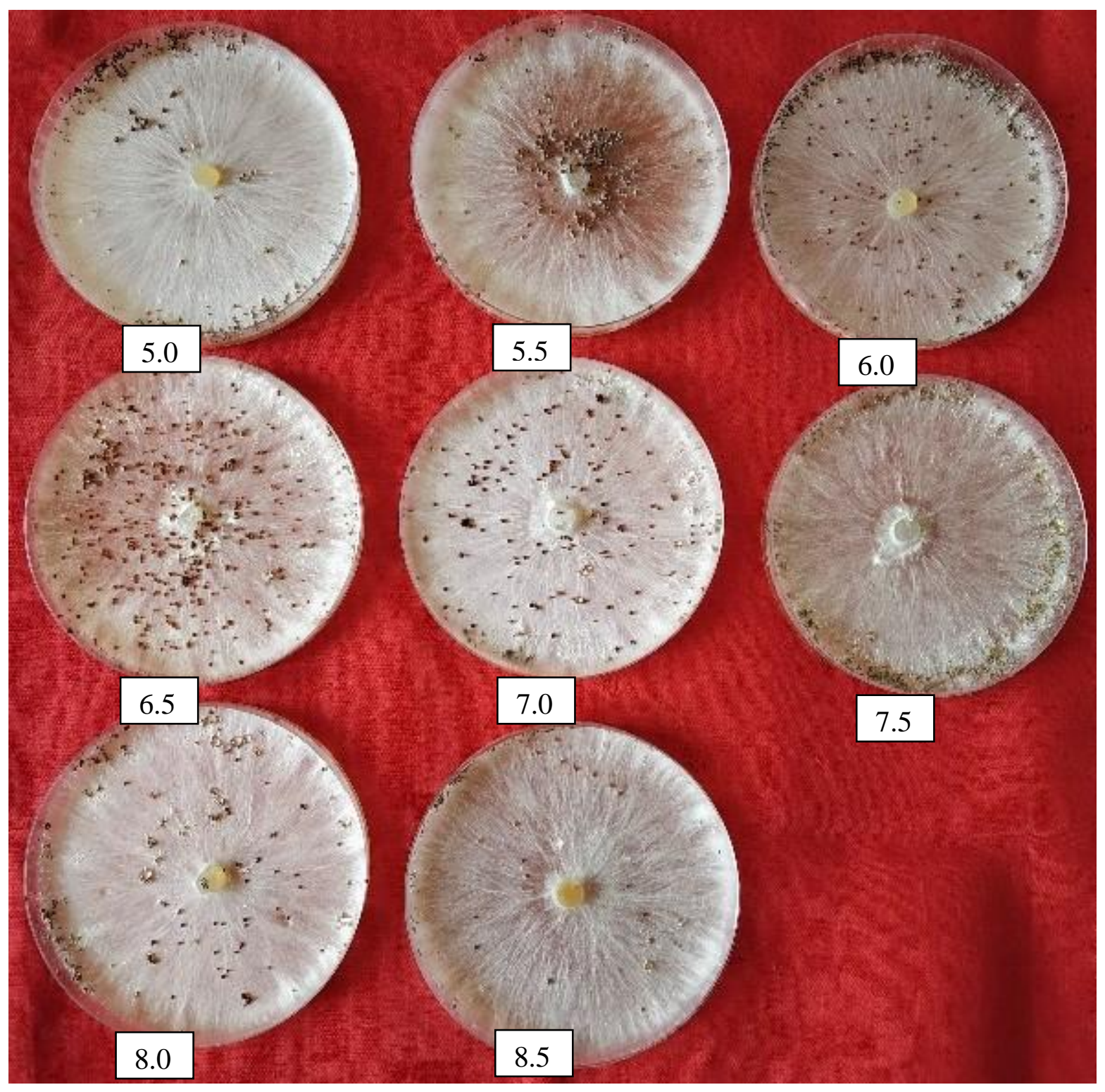




\section{References}

Ainsworth, G. C. (1961). Dictionary of fungi. Common Wealth Mycological Institute., Kew Burrey, England. p. 547.

Basamma (2008). Integrated management of Sclerotium wilt of potato caused by Sclerotium rolfsii Sacc. M.Sc. Thesis, University of Agricultural Sciences, Dharwad.

Chung H. S. and Kim, H. K. (1977). Effect of light on Sclerotium formation of Sclerotium rolfsii. Sacc. on agar media. Korean J. Mycol. 5:21-23.

Farr, D. F., Bills, G. F., Chamuris, G. P. and Rossman, A. Y. (1989). Fungi on plants and plant products in the united states. American Phytopathology Society, pp.12-52.

Punja, Z. K. and Damini, A. (1996). Comparative growth, morphology and physiology of three Sclerotium species. Mycologia 88:694-706.

Rolfs, P. H. (1892). Frist reported on tomato in Florida. (http:/eol.org/page/ 11448171/overview)

Sarma, B. K. (2002). Studies of variability, sexual sage production and control of Sclerotium rolfsii Sacc., the causal agent of collar rot of chickpea (Cicer arietinum). Ph.D., Thesis, Department of Mycology and Plant Pathology, Institute of Agricultural Sciences,
Banaras Hindu University, Varanasi, India.

Sarma, B. K., Singh, U. P. and Singh, K. P. (2002). Variability in Indian isolates of Sclerotium rolfsii. Mycologia 94:10511058.

Sharma, S. L. and Kaushal, B. R. (1979). Cultural and physiological studies with sunflower isolate of Sclerotium rolfsii. Indian Journal of the Mycology and Plant Pathology 9: 105-107.

Singh, U. P. and Pavgi, M. S. (1965). Spotted leaf rots of plants- a new sclerotial disease. Plant Dis. Rep. 49:58-59.

Singh, U. P., Sarma, B. K., Singh, D.P. and Bahadur, A. (2002). Studies on exudates depleted sclerotial development in Sclerotium rolfsii and the effect of oxalic acid sclerotial exudates and culture filtrate of phenolic acid induction in chickpea (Cicer arietinum). Can. J. Microbiol. 48:443-448.

Watanabe, T. (2002). Sclerotium sp. morphologies of cultured fungi and key species: Pictorial Atlas of Soil and Seed fungi. 2nd Edn., CRC Press, New York

Zape, A. S., Gade, R. M. and Singh, R. (2013). Physiological studies on different media, $\mathrm{pH}$ and temperature on Sclerotium rolfsii isolates of soybean. Scholarly Journal of Agricultural Science 2(6): 238-241.

\section{How to cite this article:}

Tushar V. Ghevariya and Patel, P. R. 2019. Effect of Light and pH on the Growth of Sclerotium rolfsii in vitro on Collar Rot of Indian Bean. Int.J.Curr.Microbiol.App.Sci. 8(10): 1268-1274. doi: https://doi.org/10.20546/ijcmas.2019.810.149 